\title{
PENGARUH PENGANGGURAN TERHADAP KEMISKINAN DI KABUPATEN BANGKA TAHUN 2009-2018
}

\author{
Gebila $^{1)}$ Ayu Wulandari, S.E., M.Si ${ }^{2)}$ \\ ${ }^{1)}$ Mahasiswa Fakultas Ekonomi Universitas Bangka Belitung \\ ${ }^{2)}$ DosenFakultasEkonomiUniversitas Bangka Belitung \\ E-mail: gebila8@gmail.com
}

\begin{abstract}
This study is entitled The Effect of Unemployment on Poverty in Bangka Regency. The purpose of this study was to determine the effect of Unemployment on Poverty in Bangka Regency. Hypothesis testing uses simple regression analysis. The data used in this study is Time series data from 2009-2018. The data used are secondary data for the period 2009-2018. The data analysis technique used is the type of descriptive research with a quantitative approach. The results of the study that unemployment does not affect poverty in Bangka Regency.
\end{abstract}

\begin{abstract}
ABSTRAK
Penelitian ini bertujuan untuk mengetahui pengaruh pengangguran terhadap kemiskinan di Kabupaten Bangka Tahun 2009-2018. Variabel dependen dalam penelitian ini adalah kemiskinan dan variabel Independen adalah pengangguran. Penelitian ini menggunakan pendekatan kuantitatif. Data yang digunakan adalah data Times Series dari Tahun 2009 sampai Tahun 2018 di Kabupaten Bangka. Teknik Analisis data dalam penelitian ini menggunakan analisis regresi linier sederhana. Hasil penelitian menunjukkan bahwa pengangguran tidak berpengaruh terhadap kemiskinan di Kabupaten Bangka.
\end{abstract}

\section{Kata Kunci : Penganguran, Kemiskinan, Kabupaten Bangka}

\section{PENDAHULUAN}

Indonesia sebagai salah satu negara berkembang memiliki isu pembangunan manusia yang menarik untuk diteliti. Pembangunan manusia menjadi isu yang sangat penting dalam pembangunan ekonomi karena menyangkut kualitas manusia sehingga perlu mendapat perhatian. Terdapat tiga alasan yang mendasari perlunya pembangunan manusia. 
Kabupaten Bangka merupakan salah satu Kabupaten di Provinsi Kepulauan Bangka Belitung yang sedang mengatasi tingkat kemiskinan dan pengangguran. Efek buruk dari pengangguran adalah mengurangi pendapatan masyarakat yang pada akhirnya mengurangi tingkat tingkat kemakmuran yang dicapai seseorang. Semakin turunnya kesejahteraan masyarakat karena menganggur tentunya akan meningkatkan peluang mereka terjebak dalam kemiskinan karena tidak memiliki pendapatan. Apabila pengangguran di suatu negara sangat buruk, kekacauan sosial akan menimbulkan efek buruk bagi kesejahteraan masyarakat dan prospek ekonomi dalam jangka panjang. (Permana, 2012)

\section{Tabel 1}

Jumlah Pengangguran di Kabupaten Bangka (ribu)

Tahun 2009 - 2018

\begin{tabular}{cc}
\hline Tahun & Pengangguran \\
\hline 2009 & 7.896 \\
2010 & 5.122 \\
2011 & 4.341 \\
2012 & 3.600 \\
2013 & 5.900 \\
2014 & 12.053 \\
2015 & 12.805 \\
2016 & 9.749 \\
2017 & 6.693 \\
2018 & 2.670 \\
\hline Sumber : BPS Kabupaten Bangka, 2019
\end{tabular}

Berdasarkan tabel 1 dapat dilihat jumlah pengangguran mengalami fluktuasi selama 10 tahun terakhir. Peningkatan pengangguran tertinggi di tahun 2015 sebanyak 12.805 orang dan terendah di tahun 2018 sebanyak 2.670 orang. Dari tahun $2009-2012$ mengalami penurunan, di tahun 2009 sebanyak 7.896 orang, tahun 2010 sebanyak 5.122 orang, dan tahun 2011 sebanyak 4.341 orang. Tahun 2013 - 2015 mengalami kenaikan, di tahun 2013 sebanyak 5.900 orang, tahun 2014 sebanyak 12. 053 orang, dan di tahun 2015 sebanyak 12.805 orang. Di tahun 2016- 2018 mengalami penurunan, di tahun 2016 sebanyak 9.749, tahun 2017 sebanyak 6.693 orang, dan di tahun 2018 sebanyak 2.670 orang. 


\section{Tabel 2}

Jumlah Penduduk Miskin di Provinsi Kepulauan Bangka Belitung Tahun 2009-2018

\begin{tabular}{lcccccccccc}
\hline Wilayah Babel & $\mathbf{2 0 0 9}$ & $\mathbf{2 0 1 0}$ & $\mathbf{2 0 1 1}$ & $\mathbf{2 0 1 2}$ & $\mathbf{2 0 1 3}$ & $\mathbf{2 0 1 4}$ & $\mathbf{2 0 1 5}$ & $\mathbf{2 0 1 6}$ & $\mathbf{2 0 1 7}$ & $\mathbf{2 0 1 8}$ \\
\hline Kep. Babel & 76.01 & 67.75 & 65.55 & 70.20 & 69.40 & 67.20 & 74.09 & 72.76 & 74.09 & 76.26 \\
Bangka & 20.50 & 21.70 & 15.40 & 16.48 & 16.20 & 16.00 & 17.39 & 17.29 & 16.50 & 18.02 \\
Belitung & 12.44 & 15.90 & 11.29 & 12.09 & 14.30 & 12.70 & 14.58 & 13.94 & 14.11 & 14.00 \\
B.Barat & 7.57 & 9.20 & 6.53 & 6.93 & 6.20 & 6.10 & 6.01 & 5.46 & 6.06 & 6.35 \\
B.Tengah & 10.39 & 13.10 & 9.30 & 9.95 & 9.50 & 9.40 & 10.19 & 10.36 & 11.39 & 11.12 \\
B. Selatan & 8.93 & 10.70 & 7.60 & 8.13 & 7.50 & 7.40 & 7.20 & 7.11 & 7.88 & 7.58 \\
Beltim & 9.26 & 11.10 & 7.88 & 8.46 & 7.90 & 7.90 & 8.71 & 8.48 & 8.44 & 8.93 \\
Pangkalpinang & 8.43 & 10.60 & 7.53 & 8.03 & 7.80 & 7.80 & 10.02 & 10.12 & 9.76 & 10.27 \\
\hline
\end{tabular}

Sumber : BPS Provinsi Kepulauan Bangka Belitung, 2019

Berdasarkan tabel 2 jumlah penduduk miskin tertinggi di Provinsi Kepulauan Bangka Belitung berada di Kabupaten Bangka selama 10 tahun berturut-turut. Dari tahun 2009 - 2011 mengalami penurunan, di tahun 2009 sebanyak 76.01 orang, tahun 2010 sebanyak 67.75 orang, di tahun 2011 sebanyak 65.55 orang. Dari tahun 2012 - 2014 mengalami penurunan, tahun 2012 sebanyak 70.20 orang, tahun 2013 sebanyak 69.40 orang, tahun 2014 sebanyak 67.20 orang. Dari tahun 2014 - 2015 mengalami kenaikan, di tahun 2014 sebanyak 67.20 orang, tahun 2015 sebanyak 74.09 orang. Dari tahun 20162018 mengalamai kenaikan, di tahun 2016 sebanyak 72.76 orang, tahun 2017 sebanyak 74.09 orang, tahun 2018 sebanyak 76.26 orang. Pemerintah menanggapi keberhasilan suatu daerah dapat dilihat dari tinggi atau rendahnya kemiskinan di suatu daerah.

\section{TINJAUAN PUSTAKA}

\section{Pengangguran}

Pengangguran adalah seseorang yang sudah digolongkan dalam angkatan kerja yang secara aktif sedang mencari pekerjaan pada suatu tingkat upah tertentu, tetapi tidak dapat memperoleh pekerjaan yang diinginkannya.

Upaya untuk menurunkan tingkat pengangguran sangat penting dengan adanya peganggangguran akan menimbulkan permasalahan sosial yang lain salah satunya kemiskinan. Secara teori jika masyarakat tidak menganggur berarti mempunyai pekerjaan dan penghasilan, dan dengan penghasilan yang dimiliki dari bekerja diharapkan dapat memenuhi kebutuhan hidup. Jika kebutuhan hidup terpenuhi maka tidak berada di kondisi kemiskinan. 
Sehingga dikatakan dengan tingkat pengangguran rendah (kesempatan kerja tinggi) maka tingkat kemiskinan juga rendah (Yacob, 2012).

\section{Teori Kemiskinan}

Kemiskinan adalah fenomena yang sering kali dijumpai dalam bermasyarakat. Kemiskinan juga sering dipandang sebagai gejala rendahnya tingkat kesejahteraan semata padahal kemiskinan merupakan gejala yang bersifat kompleks dan multidimensi. Berbagai program dan kebijakan untuk mengatasi masala kemiskinan ini, tetapi statistik angka kemiskinan cenderung semakin tinggi seiring dengan meningkatnya tingkat kebutuhan masyarakat. Rendahnya tingkat kehidupan dijadikan sebagai alat ukur kemiskinan hanyalah merupakan salah satu rantai dalam lingkaran kemiskinan. ( Bayo 2007)

Beban kemiskinan paling besar terletak pada kelompok tertentu. Kaum wanita pada umumnya merupakan pihak yang di rugikan.Dalam rumah tangga miskin, kaum wanita sering menjadi pihak yang menanggung beban kerja yang lebih banyak dari 13 pada kaum pria.Demikian pula dengan anak-anak meraka juga menderita akiba adanya ketidakmerataan tersebut dan kualitas hidup mereka terancam oleh karena tidak tercukupinya gizi, pemerataan kesehatan, dan pendidikan.

Selain itu timbulnya kemiskinan sangat sering terjadi pada kelompok-kelompok minoritas tertentu. Kemiskinan berbeda dengan ketimpangan distribusi pendapatan (inequality). Kemiskinan berkaitan dengan standar hidup yang absolut dari masyarakat tertentu, sedangkan ketimbangan mengacu pada standar hidup relatif dari seluruh masyarakat pada tingkat ketimpanagan yang maksimum, kekayaan di miliki oleh satu orang saja, dan tingkat kemiskinan sanagat tinggi. (Kuncoro 2006)

\section{METODE}

\section{Jenis Penelitian}

Jenis penelitian yang digunakan dalam penelitian ini adalah penelitian kuantitatif yang merupakan penelitian yang digunakan untuk menyelidiki, menemukan, menggambarkan, dan menjelaskan kualitas atau keistimewaan dari pengaruh sosial yang tidak dapat diukur atau digambarkan melalui pendekatan kuantitatif.

\section{Jenis dan Metode}


Jenis data dalam Penelitian ini menggunakan data sekunder. Data ini diperoleh dengan menggunakan studi literatur yang dilakukan terhadap banyak buku yang diperoleh berdasarkan catatan-catatan yang berhubungan dengan penelitian, selain itu peneliti menggunakan data yang diperoleh dari website Badan Pusat Statistik Kabupaten Bangka. Teknik analisis data yang digunakan untuk penelitian ini adalah teknik analisis regresi sederhana

\section{HASIL DAN PEMBAHASAN}

\section{Analisis Pengangguran}

Pengangguran di Kabupaten Bangka pada tahun 2009-2018 mengalami fluktuatif setiap tahunnya. Berikut jumlah Pengangguran di Kabupaten Bangka tahun 2009-2018, pada gambar 1

\section{Gambar 1}

\section{Jumlah Pengangguran di Kabupaten Bangka Tahun 2009-2018}

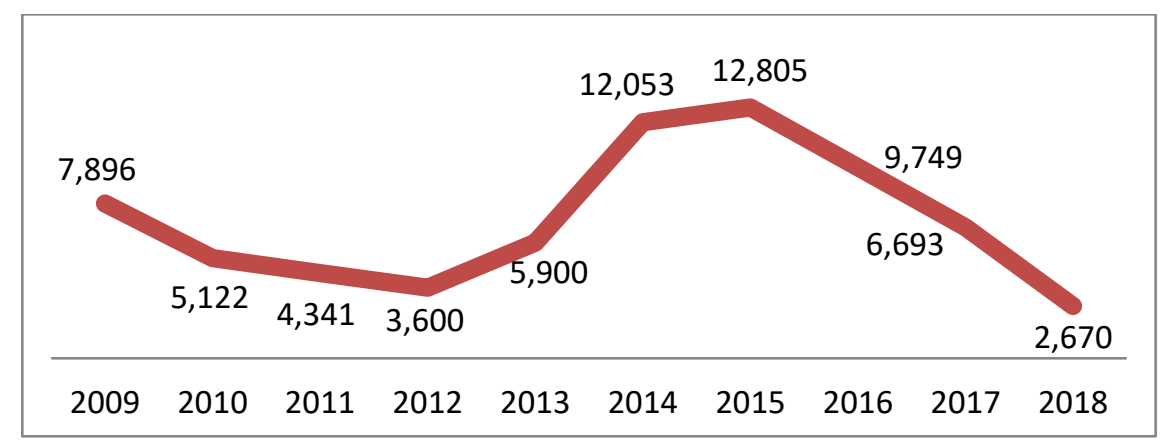

Sumber : Data diolah, 2019

Berdasarkan gambar 1 dapat dilihat jumlah pengangguran tertinggi di tahun 2015 sebanyak 12.805 orang, hal ini disebabkan lesunya perekonomian yang disebabkan banyaknya masyarakat Kabupaten Bangka yang pindah pekerjaan dari sektor pertambangan ke pertanian pasca ada nya pembatasan dalam pertambangan timah (Maesza, 2015). Jumlah pengangguran terendah berada di tahun 2018 sebanyak 2.670 orang. Tahun 2009 jumlah pengangguran sebanyak 7.896 orang. Tahun 2010-2012 jumlah pengangguran mengalami penurunan di tahun 2010 sebanyak 5.122 orang, di tahun 2011 sebanyak 4.341 dan di tahun 2012 sebanyak 3.600 orang. Tahun 2013- 2015 jumlah pengangguran meningkat, tahun 2013 sebanyak 5.900 orang, tahun 2014 sebanyak 12.053 orang dan tahun 2015 sebanyak 12.805 orang. Tahun 2016-2018 cenderung mengalami penurunan, di tahun 2016 sebanyak 9.749 orang, tahun 2017 sebanyak 6.693 orang dan tahun 2018 sebanyak 2.670 orang. 


\section{Kemiskinan di Kabupaten Bangka}

Menurut data di BPS, Kabupaten Bangka memiliki jumlah penduduk miskin tertinggi di Provinsi Kepulauan Bangka Belitung selama 10 tahun berturut-turut. Berikut jumlah penduduk miskin di Kabupaten Bangka tahun 2009-2018, pada gambar 2.

\section{Gambar 2}

\section{jumlah penduduk miskin di Kabupaten Bangka tahun 2009-2018}

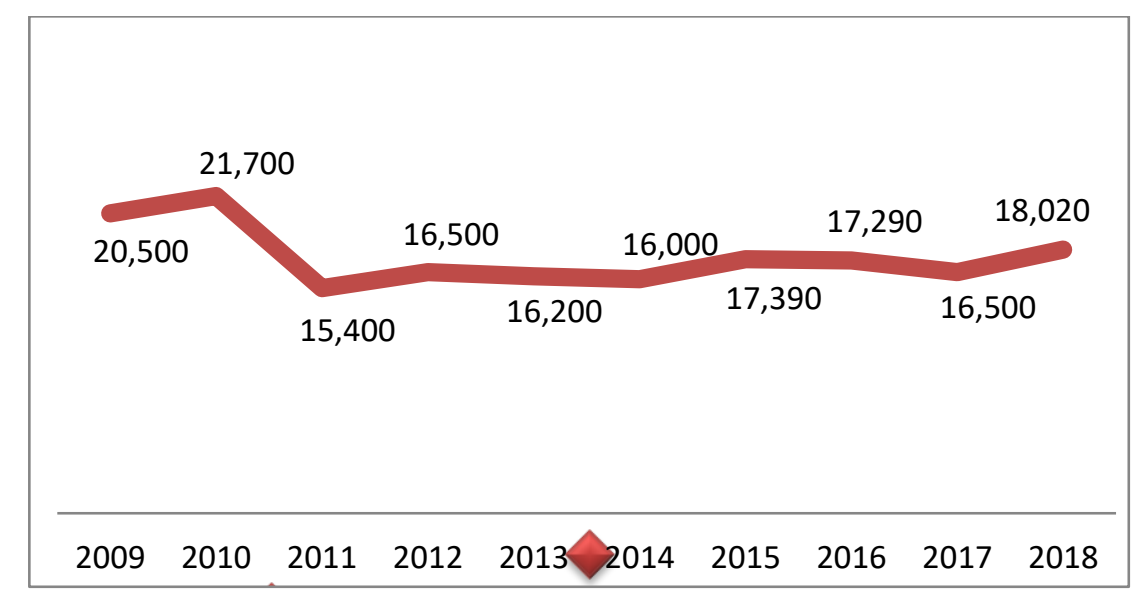

Sumber : Data diolah, 2019

Berdasarkan gambar 4.2 dapat dilihat jumlah penduduk miskin tertinggi di tahun 2010 sebanyak 21.700 orang dan terendah di tahun 2011 sebanyak 15.400 orang. Pada tahun 2018 sebanyak 18.120 orang dan mengalami kenaikan di tahun sebelumnya sebanyak 16.500 orang Pemerintah Kabupaten Bangka berusaha memaksimalkan upaya untuk mengurangi kemiskinan salah satunya dengan melibatkan lembaga analisis kemiskinan (SMERU) lembaga analisis tersebut akan mengkaji kemiskinan dan akan melakukan penelitian yang berkaitan dengan pendidikan, kesehatan dan kemiskinan. Pemerintah Kabupaten Bangka berharap dengan adanya program SMERU dapat dijadikan acuan oleh pemerintah daerah dalam mengatasi kemiskinan.

\section{Hasil Uji Regresi Linier Sederhana}


Berdasarkan hasil uji regresi linier sederhana pengaruh pengangguran terhadap kemiskinan di Kabupaten Bangka didapatkan hasil sebagai berikut:

\section{Hasil Uji Koefisien Regresi}

Tabel 3

Koefisien Regresi

\begin{tabular}{cccccc}
\hline & \multicolumn{2}{c}{$\begin{array}{c}\text { Unstandardized } \\
\text { Coefficients }\end{array}$} & $\begin{array}{c}\text { Standardized } \\
\text { Coefficients }\end{array}$ & & \\
\cline { 2 - 4 } Model & B & Std. Error & Beta & T & Sig. \\
\hline (Constant) & 17909,340 & 1605,490 & & 11,155 &, 000 \\
Pengangguran &,- 051 &, 205 &,- 087 &,- 247 &, 811 \\
\hline
\end{tabular}

Sumber : Data diolah, 2019

Berdasarkan tabel 4.4 diketahui nilai konstanta sebesar 17909,340 dan nilai koefisien regresi sebesar -0,051. Maka persamaan regresi akan di analisis dengan menggunakan hasil regresi sebagai berikut :

$$
\mathrm{Y}=17909,340-0,051 X
$$

Berdasarkan hasil model estimati dapat diinterpretasikan bahwa pengangguran mempunyai pengaruh negatif terhadap kemiskinan di Kabupaten Bangka dengan besar koefisien -0,051. Artinya apabila pengangguran naik sebesar 1 maka kemiskinan di Kabupaten Bangka turun sebesar 0,051.

\section{Uji $\boldsymbol{R}^{2}$ ( Koefisisen Determinasi)}

Tabel 4

Uji $\boldsymbol{R}^{2}$ ( Koefisisen Determinasi)

\begin{tabular}{rcccc}
\hline Model & $\mathrm{R}$ & $\mathrm{R}$ Square & Adjusted R Square & $\begin{array}{c}\text { Std. Error of the } \\
\text { Estimate }\end{array}$ \\
\hline 1 &, $087^{\mathrm{a}}$ &, 008 &,- 116 & 2150,848 \\
\hline
\end{tabular}

Sumber : Data diolah, 2019 
Berdasarkan tabel diatas menjelaskan nilai koefisien korelasi R sebesar 0,087. Dapat di tafsirkan bahwa sebesar 0,8 persen pengangguran mampu menjelaskan variabel kemiskinan sisanya 99,2 persen dijelaskan oleh variabel lain.

\section{Uji t ( Uji Parsial )}

\section{Tabel 5}

Uji t

\begin{tabular}{lccccc}
\hline & \multicolumn{2}{c}{$\begin{array}{c}\text { Unstandardized } \\
\text { Coefficients }\end{array}$} & $\begin{array}{c}\text { Standardized } \\
\text { Coefficients }\end{array}$ & & \\
\cline { 2 - 4 } Model & B & Std. Error & Beta & T & Sig. \\
\hline (Constant) & 17909,340 & 1605,490 & & 11,155 &, 000 \\
Pengangguran &,- 051 &, 205 &,- 087 &,- 247 &, 811 \\
\hline
\end{tabular}

Sumber : Data diolah, 2019

Uji t merupakan pengujian secara individual untuk membuktikan bahwa koefisien regresi ini secara statistik signifikan. Jika nilai probabilitas < dari taraf signifikan sebesar $0,05$ ( $\operatorname{sig}<\alpha 0,05)$ artinya variabel penganngguran berpengaruh terhadap kemiskinan. Jika nilai probilitas $>$ dari taraf signifikan sebesar $0,05(\operatorname{sig}>\alpha 0,05)$ artinya variabel pengangguran tidak berpengaruh terhadap kemiskiman. Dari hasil pengolahan data di peroleh bahwa nilai signifikan pengangguran sebesar $0,811>0,05$ artinya pengangguran tidak berpengaruh terhadap kemiskinan.

Berdasarkan teori yang dijelaskan di bahwa pengangguran mempunyai hubungan dengan kemiskinan dimana jika pengangguran naik maka kemiskinan juga akan naik. Namun berbeda dengan Kabupaten Bangka dimana pengangguran tidak berpengaruh terhadap kemiskinan. Hasil penelitian ini didukung oleh penelitian sebelumnya oleh (Nisbah, 2018) dan sejalan dengan De Fina (2002) menemukan bahwa kemiskinan tidak memiliki korelasi yang kuat dengan pengangguran. Defina lebih lanjut menyatakan bahwa keterkaitan antara pengangguran dan kemiskinan sangat dipengaruhi oleh bagaimana kemiskinan itu diukur. 


\section{KESIMPULAN}

Berdasarkan hasil penelitian dapat disimpulkan bahwa pengangguran tidak berpengaruh terhadap kemiskinan di Kabupaten Bangka. Dikarenakan orang yang menganggur dalam rumah tangga dihidupi oleh anggota keluarga yang pendapatannya tinggi sehingga orang yang menganggur kebutuhannya tercukupi sehingga tidak digolongkan miskin Adanya kemiskinan bukan hanya disebabkan oleh pengangguran tetapi banyak indikator-indikator yang bisa mempengaruhi kemiskinan salah satunya IPM. Hasil penelitian ini didukung oleh penelitian sebelumnya oleh (Nisbah, 2018) dan sejalan dengan De Fina (2002) menemukan bahwa kemiskinan tidak memiliki korelasi yang kuat dengan pengangguran. Defina lebih lanjut menyatakan bahwa keterkaitan antara pengangguran dan kemiskinan sangat dipengaruhi oleh bagaimana kemiskinan itu diukur.

Frances, et all bahkan menegaskan bahwa pengangguran bukan ukuran yang memuaskan kemiskinan karena pada umumnya, orang yang menganggur keadaannya lebih baik, sementara orang yang sangat miskin justru tidak menganggur, maksudnya sebagai berikut :

a. Orang yang menganggur keadaanya lebih baik karena kebutuhan ekonomi seperti kebutuhan sehari hari ada orang lain atau kepala keluarga yang memenuhi.

b. Orang yang sangat miskin justru tidak menganggur maksudnya dia bekerja namun pendapatan dan pengeluaranya di bawah garis kemiskinan sehingga di kategorikan miskin karena tidak mampu memenuhi kebutuhan sehari-hari.

Pengangguran tidak berpengaruh terhadap kemiskinan, dikarenakan orang yang menganggur dalam rumah tangga dihidupi oleh anggota keluarga yang pendapatannya tinggi sehingga orang yang menganggur kebutuhannya tercukupi sehingga tidak digolongkan miskin. Adanya kemiskinan bukan hanya disebabkan karena pengangguran tetapi banyak indikator-indikator yang bisa mempengaruhi kemiskinan salah satunya IPM.

Di Indonesia, hubungan tingkat pengangguran dan kemiskinan cenderung berbeda. Data menunjukkan bahwa pada level nasional, ketika tingkat pengangguran menurun, tingkat 
kemiskinan justru meningkat. Hubungan tersebut diperkuat dengan data pada kabupaten/kota yang menunjukkan kecenderungan yang sama seperti data pengangguran dan kemiskinan yang saya teliti dimana data pengangguran cenderung menurun dan data kemiskinan cenderung meningkat.

Di Kabupaten Bangka pengangguran rendah sedangkan kemiskinan tinggi di karenakan angkatan kerja usia 15 tahun ke atas tidak menganggur mereka bekerja di sektor informal seperti tambang timah atau perkebunan lada namun pendapatan yang diterima sangat rendah karena timah dan lada mengalami ke kemorosotan yang mengakibatkan pendapatan yang diterima rendah dan tidak mencukupi kebutuhan. Mereka tidak menganggur tetapi di golongkan penduduk miskin disebabkan pendapatan yang di terima rendah sehingga tidak mampu memenuhi kebutuhan. Itulah penyebabnya pengangguran rendah sedangkan kemiskinan tinggi.

\section{UCAPAN TERIMAKASIH}

Puji syukur penulis panjatkan kepada Tuhan Yang Maha Esa atas Karunia-Nya sehingga dapat menyelesaikan Laporan Kerja Praktik Yang berjudul " Pengaruh Pengangguran Terhadap Kemiskinan di Kabupaten Bangka Tahun 2009 - 2018” dengan tepat waktu. Kuliah Kerja Praktik dilaksanakan dari 10 Juni sampai dengan 2 Agustus 2019. Di dalam penulisan Laporan Kerja Praktik ini penulis ingin mengucapkan banyak terima kasih kepada :

1. Ayah ( Hasan ) dan ibu ( Rini Helyani ) selaku orang tua yang selalu memberikan motivasi semangat dalam menyelesaikan Laporan Kerja Praktik.

2. Ibu Dr. Devi Valeriani, S.E.,M.Si, selaku Ketua Jurusan Program Studi Ekonomi.

3. Ibu Ayu Wulandari, S.E.,M.Si, selaku Dosen Pembimbing Kuliah Kerja Praktik di Universitas Bangka Belitung dan Ibu Rini Luciani Rahayu, S.Si, M.Stat, Pembimbing Lapangan di Badan Pusat Statistik Provinsi Kabupaten Bangka.

4. Ibu Dewi Savitri, SST, M.Si, selaku Pimpinan Badan Pusat Statistik Provinsi Kepulauan Bangka Belitung.

5. Serta seluruh teman-teman yang tidak dapat disebutkan satu persatu dalam penelitian ini. 
JURNAL MANAJEMEN KOMPETEN

Vol. 3 No. 2 Desember 2020, 23-34 
JURNAL MANAJEMEN KOMPETEN

Vol. 3 No. 2 Desember 2020, 23-34

\section{DAFTAR PUSTAKA}

Bakari, S. (2016). M P RA Impact of Exports and Imports on Economic Growth in Canada: Empirical Analysis Based on Causality Impact of Exports and Imports on Economic Growth in Canada: Empirical Analysis Based on Causality. 75910. https://mpra.ub.unimuenchen.de/75910/

Cruz, A. P. S. (2013). No Title No Title. Journal of Chemical Information and Modeling, 53(9), 1689-1699. https://doi.org/10.1017/CBO97811074 15324.004

Diah Paramita, A., \& Purbadharmaja, I. (2015). Pengaruh Investasi Dan Pengangguran Terhadap Pertumbuhan Ekonomi Serta Kemiskinan Di Provinsi Bali. E-Jurnal Ekonomi Pembangunan Universitas Udayana, 4(10), 1194 1218.

Diah Retnowati. (2014). Pengaruh Pengangguran Terhadap Tingkat Kemiskinan Di Jawa Tengah. Pengaruh Pengangguran Terhadap Tingkat Kemiskinan Di Jawa Tengah, 608-618.

Di, K., \& Karisidenan, E. K. S. (2019). Analisis faktor-faktor yang mempengaruhi kemiskinan di eks karisidenan surakarta.

Pdrb, A. P., Terhadap, P., \& Jawa, P. (2018). Analisis Pengaruh PDRB, Pengangguran dan Pendidikan Terhadap Tingkat Kemiskinan di Pulau Jawa Tahun 2009-2016. Economics Development Analysis Journal, 7(1), 23-31. https://doi.org/10.15294/edaj.v7i1.2192 2

Probosiwi, R. (2016). Pengangguran dan Pengaruhnya terhadap Tingkat Kemiskinan. Balai Besar Penelitian Dan Pengembangan Pelayanan Kesejahteraan Sosial (B2P3KS), 1, 89100.

Susanto, E., Rochaida, E., \& Ulfah, Y. (2018). Pengaruh inflasi dan pendidikan terhadap pengangguran dan kemiskinan. Inovasi, 13(1), 19. https://doi.org/10.29264/jinv.v13i1.243

Yacoub, Y. (2012). Pengaruh Tingkat Pengangguran terhadap Tingkat Kemiskinan Kabupaten / Kota di Provinsi Kalimantan Barat. 8, 176185.

Zuhdiyaty, N., \& Kaluge, D. (2018). Analisis Faktor - Faktor Yang Mempengaruhi Kemiskinan Di Indonesia Selama Lima Tahun Terakhir. Jurnal Ilmiah Bisnis Dan Ekonomi Asia, 11(2), 27-31. https://doi.org/10.32812/jibeka.v11i2.4 2 